\title{
A Character Trait, or a Political Commitment?
}

Michael Martens: Im Brand der Welten: Ivo Andrić, ein europäisches Leben. Wien: Paul Zsolnay, 2019. Pp. 494. Bibliography and index.

It seems that the significance of Ivo Andrić's work increases as the decades go by: more articles, books, and new translations of his novels and stories are published now than the time of his death half a century ago. Martens' new biography is another valuable addition to this already extensive library. This is not the first biography of Andrić, however: his life has already been well researched and presented in a number of volumes in Serbo-Croat, and one in English. ${ }^{1}$ The most extensive is Žaneta Đukić-Perišićs, which in the manner of 'life and work' studies presents all significant data and synthesizes a number of specialist studies devoted to particular periods of Andrićs life. ${ }^{2}$ Among the latter, especially valuable are Želimir Bob Juričić's and Dušan Glišović's studies of Andrić's time in Berlin immediately prior to the Second World War, Ratko Peković and Slobodan Kljakić's book about the years immediately after it, and Miroslav Karaulac's two volumes about his life up until the beginning of the war. ${ }^{3}$ Also, Sveske, the annual publication of the Andrić Foundation in Belgrade, for almost forty years has been publishing biographical studies, memoirs and correspondence, all of which contributes to the impression that his life has been well researched, and that there are few reasons to expect some new and significant discoveries in the future. All that remains is reassessment, or re-contextualization, of what has already been found, and Martens cannot be criticized for a lack of significant new data from this already well-researched field. The only two novelties Martens mentions will come as a surprise to Andrić specialists, who may regret that the author did not supply any evidence for them. The first is his claim that Andric joined Jugoslovenska radikalna zajednica, the political party established by Prime Minister Milan Stojadinović. This is not very probable: Andrić was a civil servant and served under all interwar Yugoslav prime ministers, reaching the peak of his diplomatic career during Stojadinovićs term in office, and Andrić's relationship with him was neither cordial nor politically supportive, as witnessed by Andrić's close friend Lepa Pavlović in an article listed in Martens' bibliography. The second claim is that in the run-up to the Second World War, Andric advocated forging closer ties with Hitler's Germany: this runs counter to everything known so far about Andrićs political opinions, and it would be very helpful if some evidence for this claim could be provided.

Martens does an excellent job in synthesizing the existing literature, and transforms our knowledge about Andrićs life into an eminently readable narrative, which can be followed effortlessly and with enjoyment. A journalist with some experience in the former Yugoslav republics, Martens wisely refrains from interpreting Andrićs novels and stories. When he does venture into this territory by quoting brief paragraphs from Andrićs works - which are intended to shed light on his life - the results are mixed, and some instances of this procedure are more convincing than others. For example, he discusses the gossip about Andrić being an

\footnotetext{
${ }^{1}$ Vanita S. Mikerji, Ivo Andrić: A Critical Biography, London: McFarland, 1990.

2 Žaneta Đukić-Perišić, Pisaci priča. Stvaralačka biografija Ive Andrića, Novi Sad: Akademska knjiga, 2012.

3 Želimir Bob Juričić, Ivo Andrić u Berlinu 1939-1941, Sarajevo: Svjetlost, 1989; Dušan Glišović, Ivo Andrić, Kraljevina Jugoslavija i Treći Rajh 1939-1941, Belgrade: Službeni glasnik, 2012; Slobodan Peković and Ratko Kljakić, Angažovani Andrić 1944-1954, Belgrade: Službeni glasnik, 2012; Miroslav Karaulac, Rani Andrić, Belgrade: Prosveta, 1980, and Andrić u diplomatiji, Belgrade: Filip Višnjić, 2008.
} 
illegitimate child - fathered by a Franciscan monk, if the source of the gossip is a Croat, or by a Bosniak bey, if the source is a Bosniak - which is perfectly acceptable: biography is a genre halfway between history and gossip, and there is nothing wrong in telling us what authors' contemporaries, friends and enemies alike, said about them. However, when Martens immediately afterwards quotes from Andrićs work a sentence about a bastard and wonders if this constitutes Andrić's cyphered confession, the reader will justifiably raise eyebrows at such interpretative procedure. Also, it could have been preferable if Martens disclosed more about the gossipers, as this could have put their claims into context. Andrićs main gossiper was Branko Lazarević, who, resembling nineteenth-century collectors of oral epic poetry, in his recently discovered diary collected everything negative and derogatory circulating in society about Andrić, adding some more items of his own making to this collection. ${ }^{4} \mathrm{~A}$ reader familiar with Yugoslav political and cultural history would know that Lazarević was, like Andrić himself, a diplomat and a writer of erudite essays in literary and art history - but less successful than Andrić in both occupations. Moreover, after the Second World War, Andrić in quick succession published his most important works and built up a significant reputation, while at the same time being in a group of bourgeois intellectuals who were not only tolerated, but were incorporated into the public and political life of the country ruled by Communists. Lazarević, however, was banished from the public sphere and spent his last years writing a bitter diary in almost total isolation and poverty. It helps when the reader is told this, as it puts into context Lazarević's testimony that nobody liked Andrić, and that he had no friends whatsoever.

Being a genre between history and gossip, biography must contextualize the private and intimate within the larger cultural, political and historical whole. Andric was a very private individual, who carefully guarded his intimacy from intrusive eyes: he didn't write a diary, he avoided confessions in correspondence and personal communication, and there is not much his biographers can sayabout his private life. On the other hand, he led what Martens' subtitle aptly terms 'a European life'. He grew up in Višegrad and Sarajevo, studied in Zagreb, Vienna and Krakow, lived in Rome, Bucharest, Trieste, Graz, Marseilles, Paris, Madrid, Brussels, Geneva and Berlin. He spoke German, French, Italian, Spanish, Polish and Russian, and his library shows a polymath with wide-ranging interests. Life led him from being a member of the Young Bosnia movement before the First World War, to heading the Yugoslav embassy in Berlin before the Second - thus making him, as Dušan Glišović noted, the only person who met both Gavrilo Princip, Archduke Franz Ferdinand's assassin, and Adolf Hitler - and from being a trusted diplomat in the Kingdom of Yugoslavia to a respectable public figure in the socialist one. He witnessed the rise of Fascism in Rome and the triumph of National-Socialism in Berlin, lived through both world wars and saw the Communist takeover of Yugoslavia: his life is intertwined with many traumatic events in European twentieth-century history, and almost overlaps with the life of Yugoslavia. In the absence of personal details, his biographies always focus on the historical and political events and controversies, which he witnessed or participated in, and Martens' is no exception. Im Brand der Welten largely consists of Martens' contextualization of Andrićs life within the turmoil of these two frameworks: Europe and Yugoslavia.

\footnotetext{
${ }^{4}$ Branko Lazarević, Dnevnik jednog nikoga, Belgrade: Zavod za udžbenike, 2007.
} 
It must be noted that Martens' assessment of Andrić's life is strongly influenced by his own explicit dislike of Yugoslavia, and that this provides a specific lens through which the author interprets all of Andrić's convictions and actions. This angle, from which Martens approaches the contextualization of Andrić's life, is directly opposed to what was the central and most important constant of Andrić's biography: he was a lifelong political and cultural Yugoslav, from the times when he coordinated the unification of Serbian and Croatian student societies in Sarajevo before the First World War, to the end of his life, when he confessed to Ljubo Jandric that even if united, Yugoslavs were hardly capable of dealing with the challenges of history, and that if separated - as they were throughout their history, or in the present time - they were doomed to being dominated by others. Martens does not conceal Andrićs support for Yugoslavia in whatever shape or form it may have been constituted, but as his own starting point is different, Martens' narration necessarily produces a number of errors of judgement, omissions and contradictions, and a somewhat slanted framework into which Andrić's life should be fitted. This becomes obvious from the very beginning of the book: Martens assumes that there was universal Croatian opposition to the creation of a South Slav state - ignoring the strong Yugoslav current in Croatia, especially at the beginning of the twentieth century, and only strengthened by the threat of losing Dalmatia to Italy if left in the camp of those who were on the losing side of the war - but does mention that 50,000 Zagrebians came out to greet king Aleksandar Kara đorđević on his first visit to Croatia's capital city. Zagreb had 80.000 inhabitants in 1910, and 108.000 in 1921: fifty thousand was at least every other Zagrebian, which is poor proof of rejection. Admittedly, the unification of Yugoslavia was not preceded by a plebiscite, as Martens emphasises, but he goes a bit too far when he states that the civil war, which started in Yugoslavia in 1941, was a belated plebiscite: that 'plebiscite' was organized by the German attack and the destruction of the country. Martens emphasises all the shortcomings of Yugoslavia, whether real or invented, and discusses Croatian dissatisfaction with its unitary constitution at length. However, he never mentions the Cvetković-Maček agreement in 1939, which created an autonomous Croatia within Yugoslavia, and which was the first step towards a federation. Moreover, there is not a single sentence in this book which would inform a reader not familiar with Yugoslav history that after the Second World War the country become a federation, and under the 1974 Constitution a confederation of six republics; said reader will necessarily assume that throughout its history, Yugoslavia was what Martens described as a unitary state under the Karađorđević dynasty in 1918. Further, Martens views Yugoslavia from the vantage point of 1991, which occasionally leads him to anachronistic presentation: he emphasises the fact that Macedonians, Montenegrins and Bosniaks (Bosnian Muslims) were not 'recognized' as nations in the Kingdom of Yugoslavia - as if nations were eternal entities waiting to be 'recognized', and not historical constructs: between the world wars, Bosnian Muslims still thought of themselves as a religious community, and not a nation, Montenegrins viewed themselves as the best Serbs, and Macedonians had only just begun - through the work of a few isolated individuals - to assemble elements which would help the Communist Party to overcome pro-Bulgarian and pro-Serbian sentiments and to construct the nation after the Second World War. Martens claims that in 1918, Bosnia and Herzegovina was a terra incognita for Serbs living in Belgrade - despite the fact that at the time Serbs were a plurality in Bosnia, that many Bosnian Serbs studied in Belgrade, as there was still no university in Sarajevo, and that Serbs from both banks of the Drina were connected by family, cultural and business ties. What is more, Martens sums up the debate held in Yugoslav academic circles in the late 1970s and early 1980s, when Aide-Mémoire on Italian-Yugoslav relations with regards 
to Albania was discovered and ascribed to Andrić - although Martens correctly warns that this authorship is not wholly certain - and puts it into context by reminding the reader that 'forced deportations' were a common political solution in early twentieth-century Europe, and that Andrić was merely a child of his time. ${ }^{5}$ This document, however, does not mention any forced deportations, but refers to a convention which should have regulated the emigration of Muslim Yugoslavs - mostly ethnic Turks, but also Muslim Albanians - to Turkey. Following the Immigration Act (Iskan kanun) in 1934, which aimed to facilitate the repopulation of Anatolia following the Armenian genocide and expulsion of Greeks, Turkey initiated the signing of such conventions with Balkan states, and signed one with Romania in 1936. ${ }^{6}$ A similar convention with Yugoslavia was signed in 1938, but was never ratified and not put into effect. According to the terms of this convention, Yugoslavia would have allowed Muslim Yugoslavs who wanted to move to Turkey to renounce their citizenship - so 'forced expulsion' is an inadequate description of what this Aide-Mémoire refers to - and would have compensated them for property they left behind, while Turkey would have agreed to let them in and help them settle. In Europe between the World Wars, it was commonly assumed that minorities hostile to the state were a security risk, and that resettlement was a legitimate remedy: for example, Noel Buxton, 'the Balkan hand' of British politics, advocated 'an organized system of intermigration' and 'exchange of populations' in the Balkans as early as 1915 , as preferable to oppressive and violent expulsion. ${ }^{7}$ A German readership may not notice all these contradictions and omissions, but every ex-Yugoslav reader would be aware of them.

In addition to this, there are factual errors in the presentation of the framework of Andrićs lifelong commitment. Martens claims that prime minister and minister of foreign affairs Milan Stojadinović - under whom Andrić served as assistant minister - forbade Jews from study at universities, but that act, which instituted numerus clausus limiting the number of Jewish students, was introduced only in 1940 when the Cvetković-Maček government succumbed to German pressure. Slovenia had no movement for secession from Yugoslavia in 1940: on the contrary, Slovenes were ardent Yugoslavs at the time, well aware of what was happening with Slovenes in Italy and Austria and knowing that their national survival was guaranteed only by the existence of the larger South Slav state. Some readers will detect a malicious tone in Martens' note that Serbs celebrate the murder of the Ottoman sultan Murad and Austrian Archduke Franz Ferdinand on 28 June 1389 and 1914 respectively. On that date, Serbs commemorate the battle of Kosovo, which was the beginning of the loss of their independent medieval statehood, and such commemorations have thus far only been organized twice in Serbia - in 1889 and 1989 - and once in the United Kingdom, in 1916, when on 28 June all British students observed 'Kosovo day'. In any event, that date seems to have a greater significance in West European journalism than in Serbian public life, whe re it regularly passes unnoticed. Martens also leaves the impression of believing that Andric was exceptionally honoured by being incorporated into the system of the socialist Yugoslavia, and by receiving tenancy rights for a flat - when he was already 66 years old - while, in actual fact, the

\footnotetext{
5 'Aide-mémoire o albanskom pitanju', Sveske Zadužbine Ive Andrića 5/1988.

${ }^{6}$ On the Turkish immigration policy see Ahmet Akgündüz, 'Migration to and from Turkey 1783-1960', Journal for Ethnic and Migration Studies, 24.1(1998); on the Turkish-Yugoslav convention, Edvin Pezo, 'Komparativna analiza jugoslovensko-turske Konvencije iz 1938. i džentl menskog sporazuma iz 1953. Pregovori oko iseljavanja muslimana iz Jugoslavije', Tokovi istorije 2/2013.

${ }^{7}$ Noel Buxton, M.P., and Charles Roden Buxton, The War and the Balkans, London: George Allen \& Unwin, 1915, pp. 108-109.
} 
Communist Party of Yugoslavia after 1945, having so few members with a higher education and experience in running the state, had to 'honour' many professionals, intellectuals and civil servants of the previous regime, filtering them only by their behaviour during the occupation and by any explicitly professed anti-Communism. Tenancy rights were distributed by the Society of Writers, and many a younger writer had received one before it was Andrićs turn.

This is the slanted framework into which Martens tries to fit Andrićs lifelong commitment to Yugoslavia. In his book, this framework is set alongside Martens' imperial imagination and the presentation of Austria-Hungary, the state Andrić rebelled against as a young student in Sarajevo. Martens reproaches Andrić for opposing Austria-Hungary, 'whose citizen he was' he became a citizen when Austria-Hungary annexed Bosnia and Herzegovina in 1908, also without any plebiscite, which Martens surprisingly does not require in this case - and for never rebelling against the first and second Yugoslavia, but rather 'adjusting' to them. Compared to the Communist 'human shredder', claims Martens, Austro-Hungarian imperialism was the 'gentlest prelude'. Also, compared to the Kingdom of Yugoslavia, postwar Austria and Hungary faired better, as they introduced women's suffrage as early as 1918, while Yugoslavia did not do so until 1945, says Martens. Perhaps. Everything depends on the criterium we decide to employ. The Soviet Communist 'human shredder', for example, introduced full voting rights for women in 1917, a year before Austria and Hungary (where it was limited to literate women over 24 years of age). What is more, already in 1933 Austria became an (Austro-)Fascist state, and Hungary, after first the Red and then the White Terror, was ushered into Horthy's dictatorship which gradually morphed into Fascism in the 1930s. This was certainly not the happiest of times for Europe - various kinds of human shredders were working at full speed, but Andrić hardly had any reasons to regret his revolutionary, anti-imperialist and anti-colonial youth engagement: namely, he had first-hand experience of this 'gentlest prelude'. Martens also corrects Andrić's understanding of the Ottoman Empire and its rule over the South Slavs, pointing out that during its first two centuries in the Balkans the Empire was in no way 'backward'. It certainly was not: triumphing empires never are, as the Inca, for example, quickly learnt when they met the advanced Spaniards. However, colonial populations rarely like the empires 'whose citizens they are', and reserve the right to dissenting opinion when it comes to the advantages of foreign rule, especially if they write as Andric did - their PhD dissertations on the results of Ottoman rule in Bosnia, and not on its initial comparative advantages.

This is, in my opinion, the root cause of the misguided portrait of Ivo Andric in Im Brand der Welten. Throughout the book Martens characterizes Andrić as opportunist, and at the very end points to opportunism as Andrić's main character trait. Yet it seems that Martens' evidence of Andrićs opportunism is a bit stretched, and that he sometimes ignores the evidence to the contrary which he himself supplies. For example, as one of the proofs of Andrićs alleged cold, calculating and opportunistic nature, Martens mentions Andrićs friendship with Marko Ristić during the Second World War, which brought Andrić some 'very practicable advantages' when after the war Ristić joined the upper echelons of the Communist government. We are led to believe that Andric already in 1942 knew that the few hundred Communist-led partisans would be victorious at the end of the war, amass an army of 100,000, take over the state, forgive Marko Ristić his inter-war dissident views, which 
positioned him outside the Communist mainstream and the Party, and make him the ambassador to France. Could anyone has known all of that in 1942 ?

Even more indicative is Martens' interpretation of Andrić's long 1930 essay 'Simon Bolivar, the Liberator'. Andrić had a soft spot for anti-imperialist figures, and among the few essays he wrote, several were devoted to them: Bolivar, Rigas Feraios, Petar Petrović Njegoš and Petar Kočić. Writing about Bolivar, Andrić emphasises his democratic convictions, inspired by both the French and the American revolutions, at the same time noting that Bolivar wanted to rule as a dictator, and that his disappointment and bitterness frequently led him to decisions and actions which gave his opponents ammunition for criticizing his authoritarian behaviour. Yet, it is clear that Andric viewed Bolivar as a tragic figure who deserved his sympathy, and even admiration: Bolivar was the Liberator, even if he failed to meet the highest standards of democracy and liberalism. For Martens, this essay is only further proof of Andrićs opportunism, as he sees in it - in the same manner as he previously interpreted Andrićs mention of a 'bastard' as the cyphered confession of his own illegitimacy - a justification of King Aleksandar Karađorđević, who in 1929 dissolved parliament and ruled without it until he was assassinated in Marseilles in 1934. The essay on Bolivar is, Martens claims, a eulogy to the dictator-king, Andrić's employer. With this biographical essay, Andrić lent his support to dictatorship and authoritarianism, which, incidentally, also paid well.

There are several aspects of this interpretation one could take issue with. Bolivar did fail to meet twenty-first century standards of democracy, but so did Fernando VII, the Spanish king Bolivar fought against, who upon taking the throne in 1814 not only abolished all freedoms guaranteed by the 1812 constitution, reinstated seignorial and ecclesiastical jurisdictions, restored feudal relationships and the Inquisition, began a total war against his opponents and ruled by repression and terror, but also sent an army to reconquer the empire's American possessions. Clemens von Metternich, the real ruler of the 'gentlest prelude' that was the Habsburg Empire in Bolivar's time, was also hardly a model democrat, let alone a liberal: he called the Upper Austrian diet to meet only for three hours per year, closed down the Hungarian and Transylvanian ones, and arrested their most vocal members, while reconquering the Empire's former possessions in the Tyrol and Lombardy, adding to it Istria, Dalmatia and Venice, and annexing Krakow and Salzburg. Democracy and liberalism were hard to come by in Bolivar's time, yet, what for Andrić was the most important about him the Liberator - remains totally invisible from Martens' vantage point. The likes of Bolivar and Andrić never get a fair hearing in the court of imperial imagination.

The second objection can be best presented with the following question: do we need to assume a hidden political or personal agenda behind every publication by an author we are studying? As Martens most probably wrote this biography out of interest for one of the greatest twentieth-century writers, who was also fortunate enough to have had an eventful European life, it would be prudent to assume that Andrić wrote Bolivar's biography out of interest for the life and work of a person several South American countries celebrate as their Liberator and hero, who also with his energy, single-mindedness, persistence, and ultimate failure resembles a tragic hero, and thus becomes eminently narratable, and shares with Andrić one important value: anti-imperialism. The parallel with king Aleksandar Karađorđević can only be in the eye of the interpreter, so great are the differences between Bolivar and the king: or, if one insists, that same parallel can be drawn between Bolivar and any other early 
twentieth-century ruler with less than perfect democratic and liberal credentials. The inscription of opportunistic motives, however, in the absence of any evidence, hardly convinces the reader.

However, one could also question why Andrić decided to write about Bolivar, and not about Fernando VII or Metternich in the first place. This is the blind spot of the imperial imagination and the reason why, despite the obviousness of the answer, from this point of view Andrićs motives must always be understood as base instead of noble. Martens sees Andrić as someone who played the hero against the gentlest Austria-Hungary, which was easy and costfree, but remained silent faced with the horrors of King Aleksandar and Communist Yugoslavia, choosing to adjust to, instead of rebelling against, them. Martens interprets it as Andrić's opportunism, without explaining why Andrić chose not to be opportunistic in his youth. Even if in several places in the book he mentions Andrićs unconditional support for the South Slav state - be it unitary or federal, liberal or Communist - Martens does not translate this into psychological energy which might have directed all of Andrićs values, choices and actions, and remains attached to explaining everything as the result of Andrićs opportunism. The imperial imagination cannot understand what is plainly obvious even in the remotest Peruvian or Bosnian villages: with a democratic deficit being similar or equal, Bolivars are always preferable to Fernandos and Metternichs. What was the most important political constant in Andrić's life - his opposition to foreign rule, as neither Fernando VII and Metternich, nor Mussolini, Horthy, Dollfuss and Schuschnigg, nor Stalin or Churchill, cared much for justice and liberty in lands available for domination - remains totally out of Martens' sight.

On the other hand, a number of Andrić's important decisions, which Martens duly records, are never allowed to serve as evidence against his alleged opportunism. Young opportunists in Sarajevo before the First World War did not organize revolutionary societies. Opportunistic ambassadors do not resign, as Andrić did, upon realizing that the state they represent has sidestepped them and negotiated a pact they are opposed to. Opportunists would certainly remain silent in the face of the plight of Polish intellectuals in 1940, but Andrić as ambassador, did not shirk in voicing opposition with the German authorities and managed to secure the release of many of them. Opportunistic ambassadors would also accept the Gestapo's offer to go to Switzerland alone and leave their staff behind, but Andric declined this kind offer and returned with his staff to Belgrade instead, where he remained until the end of the war. Opportunists did sign the Appeal to the Serbian People, which the German occupying authorities required prominent Serbian intellectuals to sign and thus denounce the resistance movement - Branko Lazarević, the collector of all gossip about Andrić, was among the signatories - but Andrić refused to do so. Appalled by the behaviour of the Roman Catholic Church in Croatia and Bosnia during the war, Andric demanded that the entry indicating religion in his ID during the occupation be amended to 'no religion', although this automatically exposed him to the suspicion of being a Communist. He refused to publish anything during the occupation, and when explicitly asked to contribute something to Srpska književna zadruga (Serbian Literary Cooperative), sent a letter unambiguously explaining his political reasons for not doing so. None of this can serve as evidence of opportunism: these are all acts of moral integrity and courage. What Martens sees as Andrićs opportunism, a character trait, is actually Andrić's Yugoslavism, his political commitment. The paradox of the book Im Brand der Welten is that the author, who strongly dislikes Yugoslavia, writes about a 
man who once said that he would rather die than renounce it, and consequently this misunderstanding could not be avoided. This book sums up existing knowledge about Andrićs life and work correctly, and wherever he follows his Serbo-Croat sources Martens produces a good, readable, informative narration. On the other hand, by fitting Andrić's life into a slanted framework and by emphasising opportunism as his main character trait, as a formula which explains his life, Martens does not do justice either to what has been known about Andric so far, or to the evidence he himself presents. 